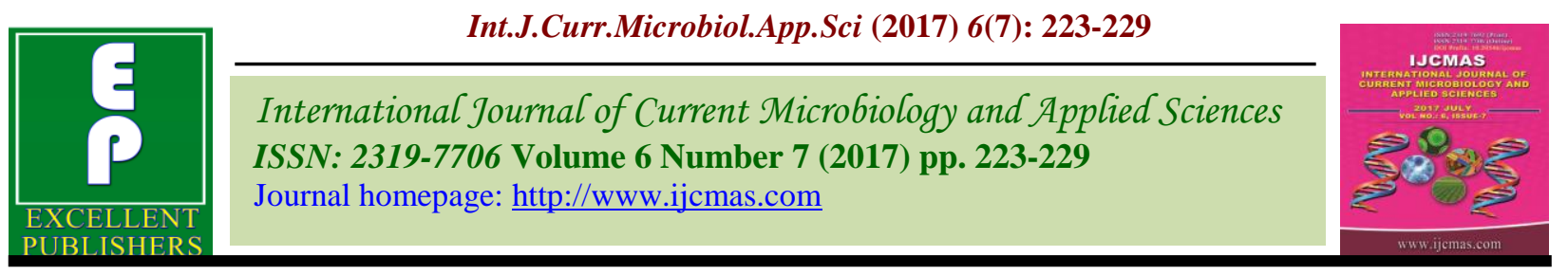

Original Research Article

https://doi.org/10.20546/ijcmas.2017.607.026

\title{
Assessment and Characterization of Soil in Sarguja District, Chhattisgarh, India
}

\author{
Sunny Abhishek Tigga*, Tarence Thomas, Arun A. David, \\ Narendra Swaroop and P. Smriti Rao
}

\author{
Department of Soil Science and Agricultural Chemistry, Sam Higginbottom University of \\ Agriculture, Technology and Sciences- Allahabad 211007, U.P., India \\ *Corresponding author
}

\begin{abstract}
A B S T R A C T
Keywords

District, Block,

Villages, Soil,

Depths, Nutrients

etc.

Article Info

Accepted:

04 June 2017

Available Online:

10 July 2017

An investigation was carried out to study the soil properties of Sarguja District. The main objective of this study is to collect information on soil $\mathrm{pH}$, electrical conductivity, organic carbon, trance element $\mathrm{N}, \mathrm{P}, \mathrm{K}, \mathrm{Zn}$, and $\mathrm{S}$. With the help of this study we found the value of $\mathrm{pH}$ is found varied from 6.9 to 6.08 . It is slightly acidic in nature. The EC value is varied from 0.335 to 0.142 and it is normal. The value of $\mathrm{OC} \%$ found is varied from $0.78 \%$ to $0.12 \%$ and this is low to medium level. The value of available nitrogen $\left(\mathrm{kg} \mathrm{ha}^{-1}\right)$ found is varied from $264 \mathrm{~kg} \mathrm{ha}^{-1}$ to $173.4 \mathrm{~kg} \mathrm{ha}^{-1}$ and this is low level. The value of available phosphorus $\left(\mathrm{kg} \mathrm{ha}^{-1}\right)$ found is varied from $25.4 \mathrm{~kg} \mathrm{ha}^{-1}$ to $10.5 \mathrm{~kg} \mathrm{ha}^{-1}$ and this is low level. The value of available potassium $\left(\mathrm{kg} \mathrm{ha}^{-1}\right)$ found is varied from $110.4 \mathrm{~kg} \mathrm{ha}^{-1}$ to $138 \mathrm{~kg} \mathrm{ha}^{-1}$ and this is low level. The value of available sulphur ( $\mathrm{ppm}$ ) is found varied from 18.5 ppm to $9.6 \mathrm{ppm}$ and this is low to medium level. The value of available zinc (ppm) is found varied from $1.62 \mathrm{ppm}$ to $0.8 \mathrm{ppm}$ and this is medium to high level.
\end{abstract}

\section{Introduction}

Soil as important part of the ecosystems which must be protected in the environment context and it is necessary to be studied the possible overall impact of measures for protection. The soil resource occupies a fundamental part of the ecosystem when a soil is degraded the others components of the ecosystems are degraded too (Robles et al., 2014).

Soils are most valuable natural resources on which the agriculture production is based. The production of food, fodder, and fuel to fulfill the ever growing needs of human being and animal are depends on Agriculture and allied per suits, based on exploration of the soil resources. Further, the varieties of industrial products are also dependent on farm and forest products directly derived from the soil Familiarity with the potentiality of soil, knowledge of their limitation and their use and method of management of soil without deterioration are important for sustained production. It is further important to bring the deteriorated land in the use after due reclamation. Knowledge of such kinds of soil and their extent is important for proper planning and optimum use for maximization 
for agriculture production. Soil survey is the only tool for making the inventory of soils (Upadhyay et al., 2014).

Soil is the basic resource for agriculture and its proper management is essential to sustain agricultural production and maintain soil productivity. Soil testing is one of the best available tools, to ascertain the physical characteristics and nutrient status of a field so as to assess the fertilizer requirements for a crop or a cropping system or for knowing the reclamation requirements if the soil is saline/sodic in nature.

Fertilizer application based on soil tests is the best available approach for harvesting the economically viable potential yields of crops by increasing input use efficiency and maintaining soil health (Singh and Brar, 2005). The production of rice crop is more in the Central part of India. Chhattisgarh is situated in the central part of India. The state of Chhattisgarh, with Raipur as its capital, came into existence on 1st November, 2000 by separation of 16 districts of Chhattisgarh region from Madhya Pradesh. At present 27 districts are there in Chhattisgarh. Chhattisgarh is situated between $22.0078^{\circ} \mathrm{N}$ latitude and $83.3362^{\circ} \mathrm{E}$ longitude in Central eastern part of India. The total geographical area of the state is 136.03 thousand sq. $\mathrm{km}$.

Geographically, Chhattisgarh is divided into three distinct land areas viz.

Chhattisgarh Plains,

Bastar Plateau and

Northern Hill Zones.

The state receives annual rainfall ranging from less than $1200 \mathrm{~mm}$ to greater than 1600 $\mathrm{mm}$ in different areas. The border of Chhattisgarh is touched by the states Uttar Pradesh in the North, Bihar in the North East, Orissa in the East, Andhra Pradesh in the
South and South East, Maharashtra in South West and Madhya Pradesh in the West. Paddy is the main crop of the state and due to abundance of production of paddy Chhattisgarh was known as 'Rice Bowl of Central India.'

A vast region of Chhattisgarh is covered by red and yellow soil. There are a number of types of soil found in Chhattisgarh area but there are four major types namely Kanhar, Matasi, Dorsa and Bhata, which cover major portion of the total land area. The red color of soil is generally related to unhydrated ferric oxide, and partially hydrated ions oxides. The yellow color in soil is also due to oxides of iron. The soils of the region are deficient in important mineral nutrients like nitrogen, phosphorous, lime and potash, which are concentrated in the lower parts of the soil layer. However, the tropical red and yellow soils or the red sandy soils of the region possess texture suitable for growing crops. For the state as a whole, the predominant soil type is red and yellow loamy Soil. The percolation/water retention capacity, as well as the productive capacity of different soils, varies. The following types of soils are found in Chhattisgarh:

\section{Kanhar (clayey)}

A low-lying deep bluish black soil with high moisture retention capacity. It is well suited for rabi crops, particularly wheat.

\section{Matasi (sandy loamy)}

This is a yellow sandy soil, with an admixture of clay. It has limited moisture retention capacity. Though used for paddy.

\section{Dorsa (clay-loam)}

This type of soil is intermediate in terms of soil moisture retention between kanhar and 
matasi. This is best described as loamy, and is a color between brown and yellow.

\section{Bhata (laterite)}

This soil is a coarse-textured, red sandygravelly soil, found on upland tops. It is deficient in minerals and other productivity enhancing nutrients.

\section{Materials and Methods}

The present study was conducted in three stages i.e. soil survey and mapping, collection of samples and their analysis for different soil parameters. The soil samples were collected from 2 blocks viz., Ambikapur and Batauli of Sarguja district (C.G) (Fig. 1). From Ambikapur block 4 villages Sakalo, Sargava, Mendrakhurd, Digma and from Batauli block 5 villages Deaori, Basen, Kunkuri, Batauli, Bhatko were selected. 27 samples were collected with different depths $(0-15 \mathrm{~cm}, 15-$ $30 \mathrm{~cm}$ and $30-45 \mathrm{~cm})$. Statistical analysis was done using standard analysis of variance. It lies between $22.9494^{\circ} \mathrm{N}$ latitude and $83.1649^{\circ}$ E longitude. 244.62 kilometres long east to west and 67.37 kilometres broad north to south, this land has as area of about 16,359 square kilometres. The high-lands of Surguja district have peculiar 'pat formations' highlands with small tablelands. The Mainpat, the Jarang pat, the Jonka pat, the Jamira pat and the Lahsunpat are the major parts of the district. The average height of area is above 600 metres $(2,000 \mathrm{ft})$. Some of peaks are Mailan 1,226 metres (4,022 ft), Jam 1,166 metres $(3,825 \mathrm{ft})$, Parta Gharsa 1,159 metres $(3,802 \mathrm{ft})$, Kanda Dara 1,149 metres $(3,770 \mathrm{ft})$, Chutai 1,131 metres $(3,711 \mathrm{ft})$, and Karo 1,105 metres $(3,625 \mathrm{ft})$. There are a number of other peaks. North-west Surguja is hilly in nature, and moving westwards, three distinct steps may be marked out: the first from Shrinagar on the east to the low-lands of Patna and Kharsawan, the second from thence to the uplands around Sonhat and the third beyond Sonhat to above a height of 1,033 metres $(3,389 \mathrm{ft})$. Central Surguja is a low basin through which the Rihand and its tributaries flow.

The $\mathrm{pH}$ was determined in 1:2 soil water suspensions using Digital pH Meter (Jackson 1958). The EC was determined in 1:2 soil water suspensions using Digital Conductivity Meter (Wilcox 1950). The organic carbon was determined by Rapid Titration Method (Walkley, 1947). Available nitrogen is a term used to describe the fertilizers. The available $\mathrm{N}<250 \mathrm{~kg} \mathrm{ha}^{-1}$ may be interpreted as low, $250-500 \mathrm{~kg} \mathrm{ha}^{-1}$ as medium and $>500 \mathrm{~kg} \mathrm{ha}^{-1}$ as high.

The soil was distilled with alkaline potassium permanganate as suggested by (Subbiah and Asija, 1956) and the ammonia evolved was determined. The available phosphorous was extracted from soil by $0.5 \mathrm{M} \mathrm{NaHCO}_{3}(\mathrm{pH}$ 8.5) solution. Phosphorous in the soil extract is determined colorimetrically using a Photoelectric Colorimeter after developing molybdenum blue colour (Olsen et al., 1954). The exchangeable potassium is extracted from $1 \mathrm{~N} \mathrm{NH4OAc} \mathrm{(pH} \mathrm{7.0)} \mathrm{and} \mathrm{K}$ was determined by Flame Photometer (Toth and Prince, 1949). The zinc was determined by (Shaw and Dean, 1952; Holmes, 1945).The sulphur was determined by (Bardsley and Lancaster, 1960).

\section{Results and Discussion}

The observations regarding $\mathrm{pH}, \mathrm{EC}$, Organic carbon, Nitrogen, Phosphorus, Potassium extracted from soil are given in figures 2 to 4 and on table 1 . The figure 2 depicts the statistical accumulation of $\mathrm{pH}$ on villages and depth which was found to be significant at both levels. The highest value of $\mathrm{pH}$ is found in Digma village at depth $0-15 \mathrm{~cm}$ (6.9). The figure 3 depicts the statistical accumulation of EC on villages and depth which was found to be significant at both levels. The highest 
value of $\mathrm{EC}$ is found in Batauli village at depth $0-15 \mathrm{~cm}(0.335)$. The figure 4 depicts the statistical accumulation of organic carbon on villages and depth which was found to be significant at both levels.

The highest value of organic carbon is found in Mendrakhurd village at depth $0-15 \mathrm{~cm}$ $(0.78 \%)$. The accumulation of available nitrogen on villages and the depth which was found are to be significant at both levels. The highest value of nitrogen is found in Sargava village at depth $0-15 \mathrm{~cm}\left(264 \mathrm{kgha}^{-1}\right)$. The accumulation of available phosphorus on villages and depth which was found to be significant at both levels. The highest value of phosphorus is found in Digma village at depth $0-15 \mathrm{~cm}\left(25.4 \mathrm{kgha}^{-1}\right)$. The accumulation of available potassium on villages and depth which was found to be significant at both levels. The highest value of potassium is found in Deaori village at depth $0-15 \mathrm{~cm}$ $\left(210.4 \mathrm{kgha}^{-1}\right)$. The accumulation of available sulphur on villages and the depth which was found are to be significant at both levels. The highest value of sulphur is found in Sargava village at depth $0-15 \mathrm{~cm}$ (18.5 ppm).The highest value of zinc is found in Batauli village at depth $0-15 \mathrm{~cm}(1.62 \mathrm{ppm})$.

Table.1 Available NPK, Zn and S in soil of Sarguja District, Chhattisgarh, India

\begin{tabular}{|c|c|c|c|c|c|c|}
\hline S.No. & $\begin{array}{c}\text { Villages with different } \\
\text { depths }\end{array}$ & $\begin{array}{c}\text { Available } \\
\text { nitrogen } \\
\left(\mathrm{kg} \mathrm{ha}^{-1}\right) \\
\end{array}$ & $\begin{array}{c}\text { Available } \\
\text { phosphorus } \\
\left(\mathrm{kg} \mathrm{ha}^{-1}\right)\end{array}$ & $\begin{array}{c}\text { Available } \\
\text { potassium } \\
\left(\mathrm{kg} \mathrm{ha}^{-1}\right)\end{array}$ & $\begin{array}{c}\text { Available } \\
\text { zinc } \\
(\mathbf{p p m})\end{array}$ & $\begin{array}{c}\text { Available } \\
\text { sulphur } \\
\text { (ppm) }\end{array}$ \\
\hline 1. & Digma $(0-15 \mathrm{~cm})$ & 212.4 & 25.4 & 194.7 & 1.4 & 15.6 \\
\hline 2. & Digma $(15-30 \mathrm{~cm})$ & 210 & 18.5 & 188 & 1.16 & 13.3 \\
\hline 3. & Digma $(30-45 \mathrm{~cm})$ & 198.5 & 16.1 & 163 & 0.98 & 10.2 \\
\hline 4. & Deaori $(0-15 \mathrm{~cm})$ & 234.1 & 23.1 & 210.4 & 1.48 & 12.7 \\
\hline 5. & Deaori $(15-30 \mathrm{~cm})$ & 212.1 & 16.7 & 198.7 & 1.3 & 11.4 \\
\hline 6. & Deaori $(30-45 \mathrm{~cm})$ & 186.2 & 13.8 & 174.7 & 0.92 & 10.3 \\
\hline 7. & Sakalo $(0-15 \mathrm{~cm})$ & 207.6 & 14.1 & 180.5 & 1.2 & 14.9 \\
\hline 8. & Sakalo $(15-30 \mathrm{~cm})$ & 184.1 & 11.3 & 175.7 & 1.18 & 11.7 \\
\hline 9. & Sakalo $(30-45 \mathrm{~cm})$ & 173.4 & 11.7 & 168.2 & 0.92 & 13.7 \\
\hline 10. & Sargava $(0-15 \mathrm{~cm})$ & 264 & 16.2 & 210 & 1.4 & 18.5 \\
\hline 11. & Sargava $(15-30 \mathrm{~cm})$ & 255 & 15.2 & 204.1 & 1.3 & 14.1 \\
\hline 12. & Sargava $(30-45 \mathrm{~cm})$ & 201.8 & 10.5 & 173.7 & 0.84 & 13.2 \\
\hline 13. & Mendrakhurd $(0-15 \mathrm{~cm})$ & 240 & 17.9 & 185.7 & 1.32 & 14.8 \\
\hline 14. & Mendrakhurd $(15-30 \mathrm{~cm})$ & 209.6 & 16.1 & 164 & 1.14 & 11.9 \\
\hline 15. & Mendrakhurd $(30-45 \mathrm{~cm})$ & 205.4 & 14.3 & 138 & 0.95 & 10.8 \\
\hline 16. & Kunkuri $(0-15 \mathrm{~cm})$ & 260 & 22.6 & 195.7 & 1.15 & 15.1 \\
\hline 17. & Kunkuri $(15-30 \mathrm{~cm})$ & 205.4 & 15.9 & 180.5 & 1.1 & 13.8 \\
\hline 18. & Kunkuri $(30-45 \mathrm{~cm})$ & 174 & 14.7 & 178.2 & 0.9 & 9.6 \\
\hline 19. & Basen $(0-15 \mathrm{~cm})$ & 234 & 18.4 & 194.1 & 1.18 & 13.4 \\
\hline 20. & Basen $(15-30 \mathrm{~cm})$ & 219.2 & 16.8 & 189.5 & 0.94 & 11.7 \\
\hline 21. & Basen $(30-45 \mathrm{~cm})$ & 215 & 14.4 & 186 & 0.8 & 10.1 \\
\hline 22. & Bhatko $(0-15 \mathrm{~cm})$ & 210.5 & 15.8 & 210.1 & 1.05 & 16.2 \\
\hline Is & Bhatko $(15-30 \mathrm{~cm})$ & 201 & 15.2 & 189 & 0.9 & 14.6 \\
\hline 24. & Bhatko $(30-45 \mathrm{~cm})$ & 198.5 & 13.4 & 172.8 & 0.84 & 13.1 \\
\hline 25. & Batauli $(0-15 \mathrm{~cm})$ & 262 & 18.7 & 201 & 1.62 & 15.7 \\
\hline 26. & Batauli $(15-30 \mathrm{~cm})$ & 230 & 18.5 & 198.1 & 1.05 & 14.5 \\
\hline 27. & Batauli $(30-45 \mathrm{~cm})$ & 205.6 & 13.6 & 174.8 & 0.84 & 10.6 \\
\hline
\end{tabular}


Fig.1 Map of Sarguja districts

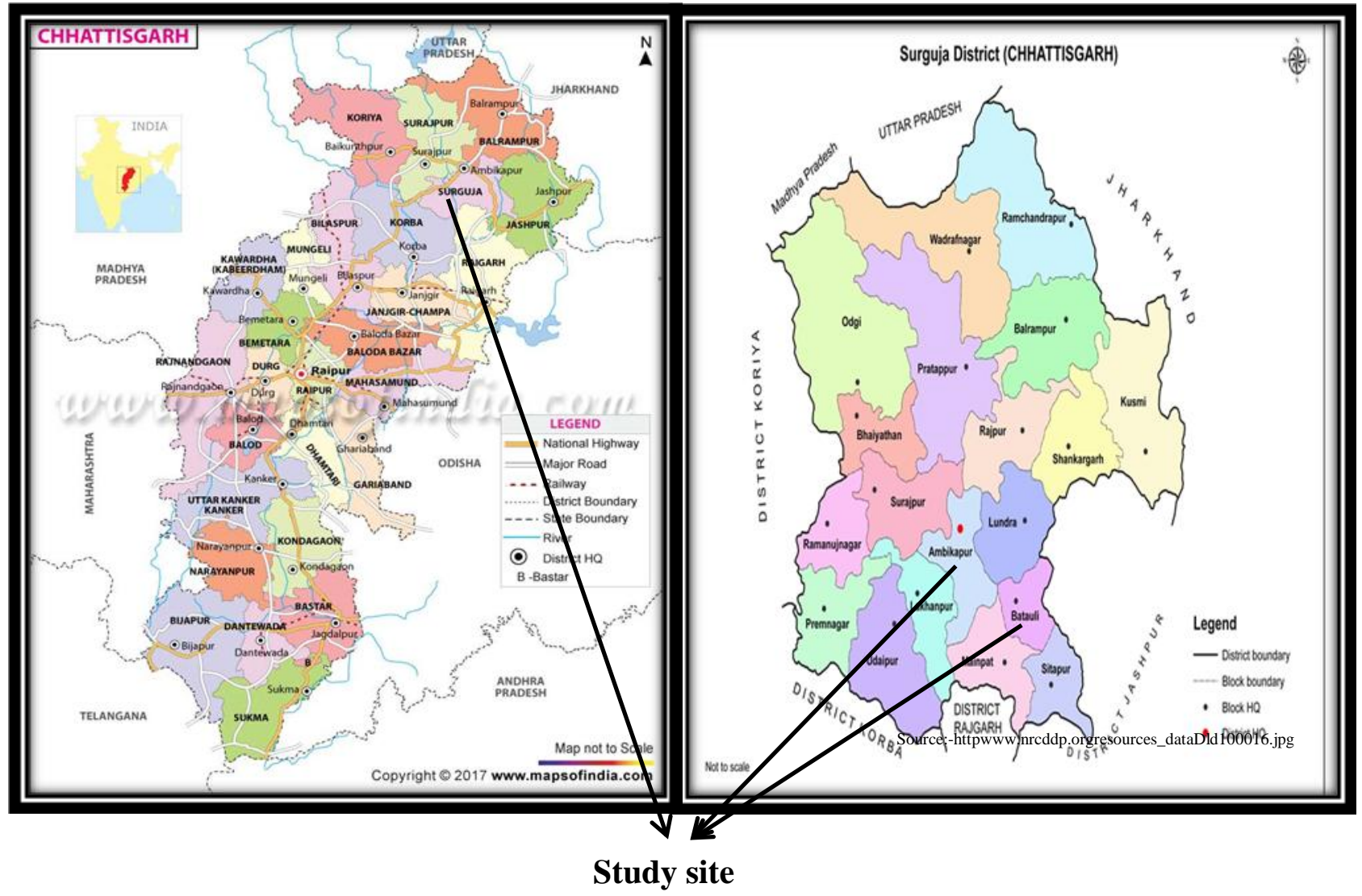

Fig. $2 \mathrm{pH}$ values of soil of Sarguja district, Chhattisgarh at (0-15cm, 15-30cm, 30-45cm) depths, 2017

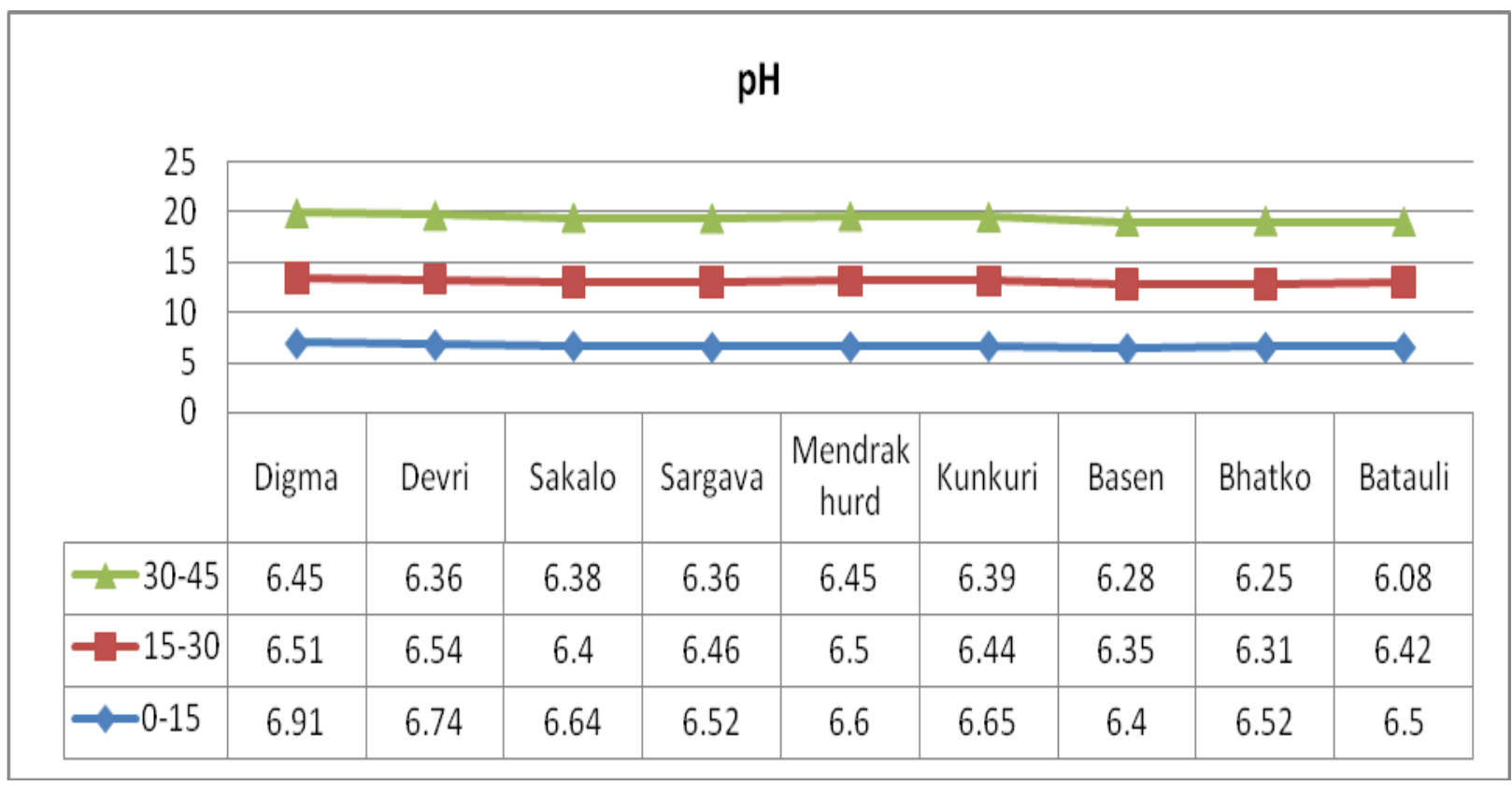


Fig.3 EC $\left(\mathrm{dSm}^{-1}\right)$ values of soil of Sarguja district, Chhattisgarh at (0-15cm, 15-30 cm, 30-45cm) depths, 2017

\begin{tabular}{|c|c|c|c|c|c|c|c|c|c|c|}
\hline \multicolumn{11}{|c|}{ Electrical conductivity } \\
\hline \multirow{2}{*}{ 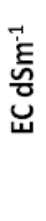 } & \multirow{2}{*}{$\begin{array}{l}0.1 \\
0.8 \\
0.4 \\
0.2 \\
0\end{array}$} & \multicolumn{9}{|c|}{2} \\
\hline & & Digma & Devri & Sakalo & Sargava & $\begin{array}{c}\text { Mendrak } \\
\text { hurd }\end{array}$ & Kunkuri & Basen & Bhatko & Batauli \\
\hline & $-30-45$ & 0.228 & 0.162 & 0.142 & 0.147 & 0.178 & 0.148 & 0.146 & 0.217 & 0.289 \\
\hline & $-15-30$ & 0.239 & 0.179 & 0.146 & 0.147 & 0.188 & 0.163 & 0.153 & 0.225 & 0.328 \\
\hline & $=0-15$ & 0.261 & 0.194 & 0.151 & 0.156 & 0.197 & 0.179 & 0.164 & 0.242 & 0.335 \\
\hline
\end{tabular}

Fig.4 OC (\%) values of soil of Sarguja district, Chhattisgarh at $(0-15 \mathrm{~cm}, 15-30 \mathrm{~cm}$ and 30-45 $\mathrm{cm})$ depths, 2017

\begin{tabular}{|c|c|c|c|c|c|c|c|c|c|c|}
\hline \multicolumn{11}{|c|}{ Organic carbon (\%) } \\
\hline \multirow{4}{*}{ c } & 1.5 & \multirow{2}{*}{\multicolumn{9}{|c|}{$\mathrm{AP}$}} \\
\hline & 1 & & & & & & & & & \\
\hline & 0.5 & \multicolumn{9}{|c|}{$\longrightarrow \rightarrow$} \\
\hline & 0 & Digma & Devri & Sakalo & Sargava & $\begin{array}{l}\text { Mendrak } \\
\text { hurd }\end{array}$ & Kunkuri & Basen & Bhatko & Batauli \\
\hline & $-30-45$ & 0.3 & 0.12 & 0.42 & 0.32 & 0.35 & 0.3 & 0.35 & 0.18 & 0.42 \\
\hline & $-15-30$ & 0.46 & 0.48 & 0.46 & 0.53 & 0.69 & 0.4 & 0.64 & 0.3 & 0.48 \\
\hline & $-0-15$ & 0.7 & 0.5 & 0.62 & 0.76 & 0.78 & 0.72 & 0.72 & 0.6 & 0.74 \\
\hline
\end{tabular}

It is concluded that the soil of Ambikapur and Batauli Block in Sarguja District of Chhattisgarh showed status according to figure 2 the value of $\mathrm{pH}$ is found varied from 6.9 to 6.08 . It is slightly acidic in nature. The EC value is varied from 0.335 to 0.142 and it is normal similarly result found (Upadhyay et al., 2014). The value of OC (\%) found is varied from $0.78 \%$ to $0.12 \%$ and this is low to medium level. The value of available nitrogen $\left(\mathrm{kgha}^{-1}\right)$ found is varied from $264 \mathrm{~kg} \mathrm{ha-}{ }^{1}$ to $173.4 \mathrm{~kg} \mathrm{ha}^{-1}$ and this is low level. The value of available phosphorus $\left(\mathrm{kg} \mathrm{ha}^{-1}\right)$ found is varied from $25.4 \mathrm{~kg} \mathrm{ha}^{-1}$ to $10.5 \mathrm{~kg} \mathrm{ha}^{-1}$ and this is low level. The value of available potassium $\left(\mathrm{kg} \mathrm{ha}{ }^{-1}\right)$ found is varied from $110.4 \mathrm{~kg} \mathrm{ha}^{-1}$ to $138 \mathrm{~kg} \mathrm{ha}^{-1}$ and this is low level. The value of available sulphur (ppm) is found varied from $18.5 \mathrm{ppm}$ to $9.6 \mathrm{ppm}$ and this is low to medium level. The value of available zinc (ppm) is found varied from $1.62 \mathrm{ppm}$ to $0.8 \mathrm{ppm}$ and this is medium to high level.

\section{Acknowledgement}

Authors are sincerely thankful to Dr. T. Thomas Head and Associate Prof., Dr. Narendra Swaroop, Associate prof., Dr. A. A David, Associate Prof. Department of Soil 
Science and Agricultural Chemistry of Naini agricultural institute SHUATS Allahabad (U.P).

\section{References}

Bardsley, C.E. and Lancaster, J.D. (1960).Determination of reserve sulphur and soluble sulphates in soil. Soil Sci. Soc. Amer. Proc. 24 265- 268

Holmes, R. S. (1945). Determination of total copper, zinc, cobalt, lead in soil and Soil solution, Soil Sci.59 77-84.

Jackson, M.L. (1958).Soil Chemical Analysis, Prentice Hall of India Private Limited, New Delhi.

Olsen, S.R., Cole, C.V., Watnahe, F.S. and Dean L.A. (1954). Estimation of available phosphorous in soil by extraction with sodium bicarbonate U.S. Dept. Agr. Cric. 939.

Pandey, A., Laxmi, R., Tiwari, J. and Sharma, R. P., (2013). Distribution of available macro and micronutrients in soils of Dewas District of Madhya Pradesh $A$ Journal of multidisciplinary advance research, 2(2) 108- 114.

Rao, P. S., Thomas, T., Singh Z. and Rachana (2016).Assessment of macronutrients in soils of Bastar Plateau Region, Chhattisgarh, India, International journal of multidisciplinary research and development3(7) 34-38.

Shaw, E. and Dean, L.A. (1952). The use of dithizone as an extractant to estimation the nutrient status of soil. Soil Sci.73 341-344.

Singh, M., and Brar J.S. (2005). The physicochemical characteristics and fertility status of soil of Amritsar district of Punjab, J. Res. Punjab agric. Univ. 42 (1) $19-27$.

Subbiah B. V. and Asija C.L. (1956). A rapid procedure for the estimation of available nitrogen in soil, Current Sci.25 259-260.

Toth, S. J. and Prince, A.L. (1949). Estimation of cation exchange capacity and exchangeable $\mathrm{Ca} \mathrm{K}$ and $\mathrm{Na}$ Content of Soil by Flame photometer technique. Soil Sci.67 439-445.

Upadhyay, M. and Chawla J. K. (2014) Chemical characteristics of soil in parts of Dhamtari District of Chhattisgarh. IJMCA, 4(13) 146-149.

Walkley, A. (1947). Critical examination of rapid method for determining organic carbon in soil, effect of variation in digestion condition and of inorganic soil constitutes. Soil Sci.632-251

Wilcox, L.V. (1950).Electrical conductivity, Amer. water works assoc. J. 42 775-776

\section{How to cite this article:}

Sunny Abhishek Tigga, Tarence Thomas, Arun A. David, Narendra Swaroop and Smriti Rao, P. 2017. Assessment and Characterization of Soil in Sarguja District, Chhattisgarh, India. Int.J.Curr.Microbiol.App.Sci. 6(7): 223-229. doi: https://doi.org/10.20546/ijcmas.2017.607.026 